\title{
Autoimmunity After Ischemic Stroke and Brain Injury
}

\author{
Ehsan Javidi* and Tim Magnus* \\ Department of Neurology, University Medical Center Hamburg-Eppendorf, Hamburg, Germany
}

Ischemic Stroke is a major cause of morbidity and mortality worldwide. Sterile inflammation occurs after both stroke subtypes and contributes to neuronal injury and damage to the blood-brain barrier with release of brain antigens and a potential induction of autoimmune responses that escape central and peripheral tolerance mechanisms. In stroke patients, the detection of $T$ cells and antibodies specific to neuronal antigens suggests a role of humoral adaptive immunity. In experimental models stroke leads to a significant increase of autoreactive $T$ and B cells to CNS antigens. Lesion volume and functional outcome in stroke patients and murine stroke models are connected to antigen-specific responses to brain proteins. In patients with traumatic brain injury (TBI) a range of antibodies against brain proteins can be detected in serum samples. In this review, we will summarize the role of autoimmunity in post-lesional conditions and discuss the role of $\mathrm{B}$ and $\mathrm{T}$ cells and their potential neuroprotective or detrimental effects.

Edited by:

Guillaume Dorothee, INSERM U938 Centre de Recherche Saint Antoine, France

Reviewed by: Tomas Per Olsson, Karolinska Institutet (KI), Sweden Arthur Liesz, Ludwig Maximilian University of Munich, Germany

*Correspondence: Ehsan Javidi e.javidi@uke.de Tim Magnus t.magnus@uke.de

Specialty section: This article was submitted to Multiple Sclerosis and

Neuroimmunology, a section of the journal

Frontiers in Immunology

Received: 09 January 2019 Accepted: 13 March 2019 Published: 02 April 2019

Citation: Javidi E and Magnus T (2019) Autoimmunity After Ischemic Stroke and Brain Injury.

Front. Immunol. 10:686. doi: 10.3389/fimmu.2019.00686
Keywords: autoimmunity, traumatic brain injuries (TBI), autoantibodies, ischemic stroke (IS), adaptive immunity, neural antigens, autoreactive $T$ and $B$ cells, neuroinflammation

\section{INTRODUCTION}

Ischemic Stroke and traumatic brain injury (TBI) cause damage to neurons, glia and the vasculature resulting in the disruption of the blood-brain barrier (BBB), hemorrhage, edema, and necrotic cell death. Cell injury and cell death lead to the release of danger signals that activate the immune system $(1,2)$. The subsequent sterile inflammatory reaction involves the innate immune system with activation of resident immune cells of the central nervous system (CNS) and a rapid infiltration of peripheral immune cells into the brain $(3,4)$. The presence of brain-derived antigens in the lymphoid tissue of stroke patients (5) and increased levels of brain antigens in the CNS and peripheral circulation in both diseases may trigger an adaptive autoimmune response. This process would require the presentation of antigen by antigen-presenting cells (APCs) to autoreactive $\mathrm{T}$ cells. The prevention of detrimental autoimmunity is usually mediated by central and peripheral tolerance mechanisms which include anergy, clonal deletion and suppression by regulatory $\mathrm{T}$ cells (Tregs) (6). Self-reactive $\mathrm{T}$ and/or B lymphocytes and/or their ability of autoantibody production can exist as physiological autoimmunity with no evidence of clinical disease, demonstrated by the presence of natural autoantibodies that are involved in homeostasis by degrading self- and foreign antigens (7). In the inflammatory microenvironment following stroke and TBI, self-reactive lymphocytes and autoantibodies could be generated and participate in inflammation, when immune tolerance is broken, leading to pathological autoimmunity, and further tissue injury. This antigen-dependent adaptive autoimmune response would therefore differ from the reactive innate immune response that involves antigen-independent deleterious effects of $\mathrm{T}$ cells found in acute experimental stroke (8). The presence of brain-reactive antibodies in stroke and TBI could be therefore an indication of an autoimmune response and multiple investigations now demonstrate their correlation to lesion size and functional outcome in stroke and TBI. 


\section{ANTIGEN SPECIFICITY IN ISCHEMIC STROKE}

Ischemic stroke leads to a sterile inflammatory response with the accumulation of microglia, and infiltration of macrophages, lymphocytes, and dendritic cells (DCs) followed by neutrophils (3). T lymphocytes can be found in human post-mortem stroke tissue to a small extent in necrotic brain parenchyma and more consistently in perivascular spaces bordering acute infarcts (9). The activation of $\mathrm{T}$ lymphocytes via an antigen dependent or independent process is still controversial and the mechanisms of $\mathrm{T}$ cell activation after brain injury are not clearly known (10).

Stroke causes the disruption of the blood-brain barrier (BBB): Infiltrating neutrophils, major promoters of BBB breakdown, through the release of metalloproteinases (MMP) such as MMP9 , together with inflammatory mediators, lead to the degradation of tight junction (TJ) proteins $(11,12)$. This first pathway could allow for the release of brain specific antigens into the peripheral vasculature, depending on the degree of $\mathrm{BBB}$ permeability and the size of brain antigens. A second pathway through the glymphatic system could allow for cerebrospinal fluid (CSF) drainage of interstitial fluid (ISF), containing extracellular solutes such as brain antigens, from the brain parenchyma, along paravenous pathways into the lymphatic circulation, eventually reaching the lymph nodes $(13,14)$. The brain lymphatic vessels lining the dural sinuses, drain to the deep cervical lymph nodes with the capability of carrying fluids, immune cells, and possibly brain antigens from the CSF $(15,16)$.

The accumulation of APCs and the upregulation of MHC II molecules in the ischemic brain $(1,17,18)$ coinciding with the peak infiltration of lymphocytes into the brain (3), could allow for an antigen-dependent $\mathrm{T}$ cell expansion in the brain itself. In experimental ischemic stroke, clonal $\mathrm{T}$ cell expansion could be detected after 7 and 14 days following stroke (19). APCs with brain antigens could also travel through the glymphatic route and brain meningeal lymphatic vessels into the lymph nodes. Providing that significantly more brain-derived antigens can be found in cervical lymph nodes of stroke patients (5), monkey experimental autoimmune encephalomyelitis (EAE) and individuals with multiple sclerosis (MS) (20) than in controls, the possibility of $\mathrm{T}$ cell reactivity to autoantigens through activation by antigen-presenting cells (APC) in the periphery and subsequent migration into the brain also exists. $\mathrm{T}$ cells monitoring the leptomeningeal surfaces could also be activated by CNS antigens presented by phagocytes, or restimulated by CNS antigens after being primed by antigens in the periphery $(21,22)$.

The development of an immune response or tolerance to brain antigens presented by APCs in lymph nodes would depend on several factors such as the activation status of APCs, costimulatory molecules, the environment of antigen presentation, or even a genetic predisposition to autoimmune disease $(23,24)$.

The role of dendritic cells (DCs), as professional antigen presenting cells, therefore deserves closer attention. DCs play a central role in maintaining immune tolerance. In a noninflammatory environment, immature DCs present self-antigens to $\mathrm{T}$ cells, leading to anergy or deletion of $\mathrm{T}$ cells to avoid autoimmunity. Immature DCs have also been found in the meninges and the choroid plexus of the CNS sampling the CSF for antigens (25). The activation of DCs by pathogen or danger-associated molecular patterns (DAMPs), leads to DC maturation and migration into draining lymph or the ischemic brain, with an increase of MHC-II and co-stimulatory proteins, relevant for $\mathrm{T}$ cell activation $(26,27)$. In experimental autoimmune encephalomyelitis (EAE), different subtypes of activated DCs with upregulated levels of costimulatory molecules are abundantly present in inflamed CNS lesions and CSF, driving proinflammatory $\mathrm{T}$ cell responses $(28,29)$. The model of EAE is induced by the priming and expansion of $\mathrm{CD} 4+$ $\mathrm{T}$ cells responding to CNS myelin antigens and the disease is initiated by re-presentation of myelin epitopes by APCs (30). Peripherally derived myeloid dendritic cells (mDCs) in EAE were found to present endogenous myelin peptide, activating naive autoreactive pathogenic $\mathrm{CD} 4+\mathrm{T}$ cells to proliferate and produce IL-17 (30). Recently, we showed that the ischemic brain is rapidly infiltrated by $\mathrm{IRF} 4^{+} / \mathrm{CD} 172 \mathrm{a}^{+}$conventional type 2 , IL-17 inducing DCs. These cells promote neutrophil infiltrating into ischemic hemispheres via induction of IL-17 in $\gamma \delta \mathrm{T}$ cells, which can be activated in a $\mathrm{T}$ cell receptor-independent manner (27). The question whether this DC population or another subtype present in the stroke brain, could mitigate an autoimmune response to brain antigens comparable to EAE, escaping tolerance mechanisms or becoming activated after reencountering naturally occurring antibodies, therefore warrants attention in further studies.

Microglia, as the major resident immune cells in the brain become activated through proinflammatory signaling as a result of brain ischemia (31). Activated microglia are involved in cytokine production, phagocytosis, and antigen presentation (1). In multiple sclerosis (MS) patients and its animal models (EAE), activated microglia and infiltrating $\mathrm{T}$ cells are found in CNS lesion (32). Activated microglia act as APCs by expressing MHC class I and II together with costimulatory molecules (33). Their role as antigen-presenting cells in stroke has received only little attention until recently. In a study of experimental brain ischemia, microglia-like cells acted as the main antigenpresenting cells for myelin oligodendrocyte glycoprotein (MOG) antigens, leading to the expansion of previously transferred 2D2 reactive $\mathrm{CD} 4+\mathrm{T}$ cells. Higher frequencies of MOG-specific $\mathrm{T}$ cells were found in the brain at day 4 and 7 after middle cerebral artery occlusion (MCAO) (34). MHC class II/TCR interaction was necessary for $\mathrm{T}$ cell expansion in the brain with the highest expression of MHC class II found on microglia-like cells. The $\mathrm{T}$ cell expansion was dependent on cerebral ischemia. This antigen-dependent $\mathrm{T}$ cell response resulted in increased neurodeficits and infarction volumes starting at day 4 after MCAO (34).

The time course of immune cell infiltration after stroke needs to be considered in distinguishing between possible antigendependent autoimmune and antigen-independent responses. Lymphocyte infiltration after experimental stroke has been suggested to take place as early as $3 \mathrm{~h}$ for CD8 $+\mathrm{T}$ cells and $24 \mathrm{~h}$ for $\mathrm{CD} 4+\mathrm{T}$ cells (35-37), while other publications report 
a delayed peak of CD4+ T cells at 3 days $(3,38)$ or 5 days $(39)$. $\mathrm{B}$ and $\mathrm{T}$ lymphocytes are present in different models of stroke up to 7 weeks after stroke onset (40).

$\mathrm{T}$ cells in the acute phase of experimental stroke have been linked to lesion volume and functional outcome (1, 41). Transgenic mice deficient of lymphocytes and antibodymediated depletion of CD4+, CD8+, and $\gamma \mathrm{t} \mathrm{T}$ cells have been associated with smaller infarcts and better functional outcome $(8,39,42-45)$.

A possible antigen-specific $\mathrm{T}$ cell response to brain antigens however would take place several days after stroke according to the time that antigen uptake, processing, presentation and finally lymphocyte proliferation would need. The attenuation of secondary stroke injury after experimental stroke by interventions targeted at $\mathrm{T}$ cells has been repeatedly shown to be within the first days. Early detrimental lymphocyte invasion has been therefore deemed antigen-independent within the first days after stroke onset (8).

Fittingly, a study of tMCAo stroke in mice, showed a significant autoimmune response to brain antigens at 4 days through 10 days after stroke, determined by an increase in autoreactive CD4+ and CD8 $+\mathrm{T}$ cells and CD19+ B cells, isolated from spleens and cervical lymph nodes (46). The peak of autoreactivity was reported to be at 8 days in splenic CD4+ T cells and at day 10 for CD8 $+\mathrm{T}$ cells in the cervical lymph nodes. An increased autoreactive response to microtubule-associated protein 2 (MAP2) and myelin derived peptides such as myelin basic protein (MBP) and MOG was associated with smaller infarct volumes and an increased autoreactive response to the anti N-methyl-D-aspartate receptor 2A (anti-NMDAR2A) with larger infarct volumes in mice (46).

In contrast to (46), a study of brain-derived antigens in the cervical lymph nodes and palatine tonsil of 22 patients with acute stroke, found increased immunoreactivity to neuronal MAP2 and NMDA NR-2A to be associated with smaller infarct volumes at day 7 and better outcome, whereas increased immunoreactivity to myelin-derived MBP was associated with more severe impairments on admission, larger infarcts and worse outcome at clinical follow-up (5). Cells immunoreactive to neural antigens were mostly CD68+ macrophages expressing costimulatory MHC II receptors and their co-localization with CD69+ T cells suggested activation of T cells (5).

There is further evidence for detrimental antigen-dependent effects: CD8 $+\mathrm{T}$ cells with a ovalbumin-specific $\mathrm{T}$ cell receptor were transferred into Rag1 mice showing no activation, less brain infiltration and smaller infarct sizes at 7 days after pMCAO than after the adoptive transfer of wild-type CD8+ T cells which could function antigen-dependently (45).

Another important question is the role of regulatory $\mathrm{T}$ cells (Tregs). The role of Tregs in the regulation of lymphocytic activity especially in light of exposure to neural antigens has not been fully answered. Tregs have a role in controlling autoreactive responses and have been shown to inhibit autoimmunity, maintaining peripheral tolerance (47). Following stroke, an early infiltration of Tregs (CD25+Foxp3+) was observed within the first week after MCAO in mice, constituting 20\% of all CD4+ $\mathrm{T}$ cells by Liesz et al. (48), while we found only $<5 \%$ of all
CD4+ T cells to be Tregs within the first week (3). Accordingly, (49) found a substantial infiltration of Tregs to be at 14 and 30 days as compared to 7 days after MCAO. Tregs, despite their delayed infiltration, have been nevertheless found to impact stroke outcomes within the first days after ischemia. It has been suggested that Tregs could target cells of the peripheral immune system early after ischemia, suppressing peripheral $\mathrm{T}$ cell activation or inhibiting autoantigen-specific clonal expansion (50). Accordingly, an increase of Tregs can be seen in the spleen following MCAO with possible implications on post-stroke immunosuppression (51). The question whether Tregs in stroke are neuroprotective or detrimental also remains disputed (52). A recent review found the majority of studies with Tregs targeted therapies to support the beneficial role of Tregs, with reduction of lesion size. Treg depletion models were more likely to show an increased infarct volume and increased leukocyte brain invasion and proinflammatory cytokine secretion, however some studies showed no effect on infarct volume (50). The difference in outcome has been attributed to the different intensity of neuroinflammation dependent on the lesion sizes in the use of different ischemia models (50). In a recent study, a substantial accumulation of Tregs in the mouse brain was detected starting a week after ischemic stroke, potentiating neurological recovery. Tregs transferred from ischemic mice accumulated more efficiently in the brain of lymphocyte deficient Rag2 -/mice than Tregs from sham operated mice, suggesting the importance of antigen recognition for Treg cell expansion in the brain (53). The involvement of Tregs in suppressing autoimmune responses to neural antigens can be deduced from studies that use tolerization to brain antigens, showing an increased probability of Treg responses and improved neurological outcome (54-56). These studies are discussed further below.

Taken together, there evidence of an antigen-specific $\mathrm{T}$ cell presence in ischemic stroke. This develops within several days and decreases over time. It is unclear however if these findings are relevant to the human stroke.

\section{T CELLS: ANTIGENS AND TOLERANCE IN STROKE}

There is evidence for $\mathrm{T}$ cell reactivity to autoantigens such as myelin basic protein (MBP) and myelin proteolipid protein (PLP) in patients with ischemic stroke (57). Higher peak concentrations of MBP, neuron-specific enolase (NSE) and S100B in the serum of patients at $24 \mathrm{~h}$ after stroke have been associated with stroke severity and larger infarct volumes (58).

If $\mathrm{T}$ cells, particularly CD4 $+\mathrm{T}$ cells, encounter an antigen, they can react in several ways. Depending on the cytokine milieu the effector function of $\mathrm{T}$ cells will be shaped (59). For example, a TH1 type response, a TH2/TH3 response, a TH17 response, an activation-induced cell death or no immune response can follow. A TH1 response (sensitization) leads to the secretion of proinflammatory cytokines after reencountering with the sensitizing antigen. A TH2/TH3 response (tolerance) leads to the secretion of immunomodulatory cytokines after reencountering with the antigen. Stroke induces an early systemic 
inflammatory response, which could promote sensitization to brain antigens in an altered microenvironment (60). It is believed that mucosal antigen administration shifts the immune response from a $\mathrm{TH} 1$ response with secretion of proinflammatory cytokines (e.g., IL-1b, TNF- $\alpha$, IFN-y) to a TH2 or TH3 response, with secretion of anti-inflammatory cytokines (e.g., TGF-b1, IL-10) that would limit cell-mediated responses and enhance humoral responses. In addition, antigen-specific regulatory $\mathrm{T}$ cells can produce anti-inflammatory cytokines after encountering a previously administered autoantigen $(60,61)$. There is evidence that $\mathrm{TH} 1$ type responses to $\mathrm{MBP}$ are associated with worse neurological outcome following experimental stroke (60, 62, 63). In one study, the adoptive transfer of MBP specific $\mathrm{TH} 1$ $(+)$ or TH17 $(+)$ cells into naïve recipient mice resulted in a worse neurological outcome (63). The adoptive transfer of splenocytes reactive for MOG into immunodeficient MCAO mice led to their migration into the ischemic hemispheres and resulted in an increased infarct volume (64). However, $\mathrm{TH} 1$ responses to antigen stimulation with $\mathrm{MBP}$ following 1 month after experimental MCAO were low and animals were more likely to develop a TH2/TH3 type response (60). Treatment with the pathogenic lipopolysaccharide (LPS) to stimulate a systemic inflammatory response, showed an increased sensitization to MBP with an increased TH1-response and more severe neurologic deficits and brain atrophy at 1 month after MCAO. This suggested that a systemic inflammation after stroke could lead to a detrimental autoimmune response $(60,65)$. LPS also induced the expression of MHC II molecules on microglia required for lymphocyte activation which are usually not expressed in the CNS (66). In a more recent study of the same group, which investigated autoimmune responses to MBP after stroke following immunization with MBP, again only 1/4$1 / 3$ of the animals had a $\mathrm{TH} 1$ or $\mathrm{TH} 17$ response to MBP. Those with a response were also associated with worse outcome at 1 month (67). The detrimental effect was observed shortly after experimental ischemia. Animals that were sensitized to MBP prior to stroke had a sharply increased mortality within $24 \mathrm{~h}$, whereas induction of oral tolerance to MBP resulted in significantly reduced infarct sizes at $24 \mathrm{~h}$ and $96 \mathrm{~h}$ after ischemia (68). MCAO animals who received splenocytes from MBP tolerized donors showed a decrease in infarct volume (69). Animals who were tolerized to MBP before MCAO induction and LPS treatment were less likely to develop a TH1 response to MBP than ovalbumin (OVA) tolerized animals and had an increased probability of a $\mathrm{TH} 3$ or TREG response together with smaller infarct sizes after 1 months (55). Similarly, mice who were previously nasally tolerized to MOG showed a significant shift from the proinflammatory cytokine IFN-y to the anti-inflammatory cytokine IL-10 after MCAO induction (61). Adoptive transfer of CD4+ T cells from nasally tolerized mice to wild-type mice showed a significant reduction in infarct size. This effect could not be observed in IL-10 deficient mice (61). Treatment with a neuroantigen-specific peptide such as recombinant $\mathrm{T}$ cell receptor ligands (RTL), linked to myelin peptide (MOG), reduced lesion size and inhibited the accumulation of inflammatory cells, presumably by inducing tolerance to MOG (70). RTL specifically targeting myelin-specific
$\mathrm{T}$ cells can modulate their characteristics to anti-inflammatory cells that secrete IL-10 (71).

Similar observations have also been made in clinical studies. In a study with 114 patients of ischemic stroke, a strong TH1 response to $\mathrm{MBP}$ at 90 days was associated with worse outcome and was more likely to develop in patients with severe stroke and post-stroke infection (72). The degree of the TH1 response however decreased over time, pointing to the possibility of immunoregulatory mechanisms (73). Recently, in brain slices from 5 patients with acute middle cerebral artery ischemic stroke, who died within 7-10 days after stroke onset, $\mathrm{T}$ cells, including MOG-specific CD4+ T cells were found in the infarct and periinfarct area close to ischemic neurons (34). In a cohort of 28 patients with milder ischemic stroke, frequencies of MOG and MBP-specific IFN- $\gamma$ responses, that were measured in peripheral blood, were increased early within the first week after stroke and decreased at 3 months. Naïve CD4+ and CD8+ T cells were also decreased within the first days after stroke, which was attributed in the context of stroke-induced immunosuppression (SIDS) to a possible adaptive mechanism, preventing long-term autoimmune responses (74). Accordingly, blockade of SIDS in transgenic mice with the CD4+ MOG $\mathrm{T}$ cell receptor, resulted in increased antigen specific $\mathrm{TH} 1$ responses at 14 days after MCAO (75).

Repetitive mucosal tolerance with low doses of antigen is known to generate regulatory $\mathrm{T}$ cells and suppress EAE by inducing peripheral tolerance (76). In one study, repetitive mucosal tolerance to E-selectin, a glycoprotein adhesion molecule expressed on activated endothelial cells after stroke, suppressed TH1-mediated delayed-type hypersensitivity (DTH) reaction to E-selectin, and increased IL-10 secretion in adoptively transferred splenocytes from tolerized animals. Reduced infarct sizes could be detected as early as 6 and $48 \mathrm{~h}$ after MCAO (54). In another study of mucosal tolerance to E-selectin, an increased neurogenesis together with increased Tregs in the cervical lymph nodes and peri-infarct region were found after pMCAO together with an improved behavioral recovery at 2-4 weeks (56).

Taken together, antigen specific tolerance can be used in some animal models to lessen stroke damage. These experiments show tolerization, however the exact mechanisms are not fully understood. This could be $\mathrm{T}$ cell modifying factors, but also possibly $\mathrm{T}$ cell independent.

\section{B CELLS: AUTOANTIBODIES IN STROKE}

B lymphocytes originate in the bone marrow and differentiate in the spleen. B cell activation occurs in the secondary lymphoid organs such as the spleen or lymph nodes and requires the recognition of antigen by $B$ cell receptors (BCR) and often signaling by $\mathrm{T}$ helper cells. $\mathrm{B}$ cells progress through an antigenindependent combinatorial rearrangement of the variable $(\mathrm{V})$, diversity (D) and joining (J) gene segments. This leads to the development of a vast repertoire of VDJ segments encoding the $\mathrm{BCR}$, capable of recognizing a huge diversity of antigens (77). Autoreactive B cells initially constitute $75 \%$ of immature B cells and undergo several selection processes in the bone marrow 
and spleen to establish self-tolerance (78). Negative selection occurs in B cells that recognize self-antigen with their B cell receptor (BCR); they undergo apoptosis, receptor editing, or anergy leading to a state of central tolerance lacking pathological autoreactivity. However, these self-tolerance mechanisms fail to delete all $\mathrm{B}$ cells reactive to brain antigens. Brain-reactive autoantibodies can be detected in $92 \%$ of human sera (79). B cells can also acquire self-reactivity through somatic hypermutation $(\mathrm{SMH})$. This process follows antigen-dependent activation and allows through affinity maturation, the diversification of B cell receptors through mutations within the variable gene regions of immunoglobulins (80). B cells can also change their constant region of their immunoglobulin heavy $(\mathrm{IgH})$ chain referred to as $\operatorname{IgH}$ class switch recombination (CSR). Naive mature B cells produce both IgM and IgD, which are the first two heavy chain segment in the immunoglobulin locus. After activation and $\mathrm{T}$ cell dependent cytokine signaling, they undergo antibody class switching to produce IgG, IgA, or IgE antibodies (80). IgM antibodies are the first antibodies to respond to antigen exposure and are associated with primary immune response. IgG are associated with the secondary immune response and represent the vast majority of serum antibodies found in humans. They are major components of humoral immunity involved in controlling infections and neutralizing pathogens and toxins.

The production of autoantibodies requires the antigendependent activation of $\mathrm{B}$ cells following ischemia. Brain antigens need to bind to the BCR of an autoreactive B cell. They are then taken up in to the $\mathrm{B}$ cells by receptor-mediated endocytosis, degraded, and presented by MHC-II molecules on the cell membrane (81). In the case of $\mathrm{T}$ cell dependent activation, autoreactive $\mathrm{T}$ cells activated by the same antigen, would need to bind to MHC-II through their T cell receptor (TCR) followed by expression of co-stimulatory factors and cytokines which promote $\mathrm{B}$ cell proliferation, somatic hypermutation and class switching. The expression of costimulatory molecules can be increased following infection (60) and the release of damage-associated-molecular patterns (DAMPs) after stroke (82). In the case of $\mathrm{T}$ cell independent activation, $\mathrm{B}$ cells are stimulated by antigens such as pathogen associated molecular patterns (PAMPs), like bacterial polysaccharides or extensive cross-linking of BCRs to repeated epitopes of an antigen. Pathogenic antigens can be increased because of post-stroke infection which is a common occurrence due to stroke-induced immunosuppression $(83,84)$. The pathway of brain antigen release, as described in the $\mathrm{T}$ cell section above, would allow antigen-dependent activation to take place in the CNS and the secondary lymphoid tissue such as the cervical lymph nodes (5).

There is evidence of an immunoglobulin production in the cerebrospinal fluid (CSF) of patients with cerebrovascular disease $(85,86)$. In the CSF of 318 stroke patients $\operatorname{IgG}$, IgM, and IgA immunoglobulin synthesis was significantly elevated in $24.8 \%$ of patients and $17.9 \%$ had CSF-specific oligoclonal IgG band, compared to $2.5 \%$ in age- and sex-matched controls (87). The absence of oligoclonal bands in the serum of stroke patients suggests an additional autoimmune B cell activation in the CNS outside of the cervical lymph nodes in the weeks after stroke (83).
Activated B lymphocytes producing IgG, IgM, and IgA could be found in the ischemic mouse brain adjacent to the lesion beginning 2 weeks following stroke with extensive infiltration at 7 weeks. The B cells were surrounded by cells expressing the dendritic cell marker CD11c, which suggests antigenpresentation. B cells that were clustered with $\mathrm{T}$ lymphocytes were compartmentalized, suggestive of structures similar to ectopic B cell follicle with germinal centers $(40,83)$. In autopsy brain tissue of 21 stroke patients, more B cells, and IgG positive antibodies were found than in controls (40). In other studies, elevated autoantibodies to brain specific neurofilaments (NF) were found in the serum of stroke patients in the first 6 months, whereas antibodies to the ubiquitous antigen, cardiolipin (CL) were not elevated (88).

There is also evidence of autoantibodies following stroke that bind to the N-methyl-D-aspartate receptor (NMDAR). The condition of Anti-NMDA-receptor encephalitis is mediated by autoantibodies that target the GluN1 (NR1) subunit of NMDA receptors in brain (89). The serum levels of autoantibodies to the GluN2 (NR2) subtype of NMDA receptors were elevated within $3 \mathrm{~h}$ and peaked at $10-12 \mathrm{~h}$ in patients after stroke or TIA (90). Patients with elevated GluN2 (NR2) antibodies before cardiac surgery were 18 times more likely to experience a postoperative neurological event such as confusion, TIA or stroke than following a negative NR2 antibody test (91). This could be due to an already compromised cerebrovascular circulation and ongoing silent ischemia. Accordingly, the presence of serum autoantibodies to the NMDA GluN2 (NR2) receptor showed a correlation with risk factors for stroke such as diabetes, hypertension or recent stroke/TIA (92). In another study, antibodies against the GluN1-S2 subunit of the NMDA receptor were found in the serum of $44 \%$ of 48 stroke patients compared to $3 \%$ in age matched healthy controls within $48 \mathrm{~h}$ of stroke onset. The presence of these antibodies was associated with worse clinical state on presentation, larger infarcts and cortical involvement (93). In contrast, increased immunoreactivity to the NMDA GluN2 (NR2) subunit in lymphoid tissue was associated with smaller infarcts within the first week of stroke (5). The early detection of increased autoantibodies levels within hours after stroke onset is suggestive of a rapid amplification of naturally occurring autoantibodies following stroke related antigen exposure (94). The role of naturally occurring $\operatorname{IgM}$ antibodies to annexin IV and a subset of phospholipids, was assessed by Elvington et al. (95). Ischemia reperfusion injury was mediated through the postischemic binding of natural IgMs to neoepitopes in the infarct area with complement activation and a proinflammatory phenotype in a $\mathrm{T}$ cell independent process.

\section{B CELLS-BENEFICIAL OR DETRIMENTAL?}

In order to assess the beneficial or detrimental effect of $B$ cells, the time after stroke and the different B cells subsets need to be considered. Regulatory B cells constitute only 0.5$0.7 \%$ of CD19+ B cells (96) and have been associated with protective effects following stroke. B cell deficient mice that received $B$ cells from IL $10^{-/-}$mice had larger infarct volumes, 
more severe functional deficits, higher mortality and increased numbers of activated $\mathrm{T}$ cells, macrophages, microglial cells, and neutrophils in the affected brain $48 \mathrm{~h}$ after stroke induction in the MCAO model (97). B cell deficient mice that received IL$10+\mathrm{B}$ cells had reduced infarcts, fewer infiltrating cells and a significant increase in regulatory $\mathrm{T}$ cells (98). The intrastriatal injection of cells, containing all $\mathrm{CD}_{1} 9^{+} \mathrm{B}$ cell subsets, into B cell deficient mice reduced infarct volumes $48 \mathrm{~h}$ after stroke onset. This would suggest a strong role for the default mixture of B cells to favor immunoregulation over inflammation early after experimental stroke (96). Conversely, (8) found B cells to play only a minor role in acute ischemia and (40) found no difference in infarct volumes at $72 \mathrm{~h}$ in $\mathrm{B}$ cell deficient mice. In the same study, a delayed detrimental role of B cells was discovered, with cognitive impairment within 7 weeks of stroke as a possible cause of post-stroke dementia. Delayed cognitive impairment was circumvented in B cell deficient mice and wildtype mice by $\mathrm{B}$ cell depletion with an antibody 5 days after stroke (40). In a cohort of 58 stroke patients, elevated titers of serum antibodies to $\mathrm{MBP}$ were associated with cognitive decline in the year after stroke (99). In other models, an early protective effect of regulatory $B$ cells and a delayed detrimental effect of B cells have been found. In EAE, regulatory B cells have only shown a protective anti-inflammatory role during early EAE induction. On the other hand, $\mathrm{B}$ cell depletion during disease expansion reduced the infiltration of encephalitogenic $\mathrm{T}$ cells within the CNS and draining lymph nodes and inhibited MOG-specific T cell expansion, dramatically reducing disease symptoms (100). In experimental brain injury models, such as spinal cord lesions, B cell deficient mice have shown improved locomotor function, and reduced lesion pathology compared with wild-type mice that had antibody producing B cells and IgGs in their CSF or injured spinal cord $(101,102)$.

Taken together there is evidence for naturally occurring brainreactive antibodies that escape tolerance mechanisms prior to stroke onset. Antibody titers and their presence are dramatically increased in the first hours and days following stroke. This would suggest a rapid augmentation of naturally occurring autoantibodies upon encountering increased levels of brain antigen. The delayed detection of autoantibodies and clusters of $B$ cells and T cells in brain lesions could indicate a stroke-related generation of novel autoantibodies. There are conflicting results regarding the detrimental or beneficial effects of brain-reactive autoantibodies in the acute phase of stroke and further studies are needed. Finally, regulatory B cells seem to be protective early in stroke, while delayed detrimental effects have been shown for B cells.

\section{BRAIN TRAUMA}

Traumatic brain injury (TBI) involves a primary injury with multifocal damage to axons, glia, dendrites, and a microvasculopathy with microbleeds, endothelial damage, and breach of the blood brain barrier (BBB) $(103,104)$. Similar to stroke, it is followed by a secondary injury involving an inflammatory reaction with pro-and anti-inflammatory cytokines, microglial activation, invasion of peripheral neutrophils, lymphocytes and macrophages (105), damaging levels of glutamate (106), and free radicals $(107,108)$.

Biomarkers that have been identified in human and animal biofluids after TBI include, glial fibrillary acidic protein (GFAP), myelin basic protein (MBP), neuron specific enolase (NSE), glia calcium-binding protein S100B, ubiquitin carboxyl hydrolase-like 1 (UCHL1), $\alpha$ II-spectrin fragments, and neurofilament proteins (109-115). The release of these brain proteins from injured cells into the bloodstream and the aforementioned neuroinflammatory response can trigger an autoimmune response with the generation of autoantibodies.

\section{AUTOANTIBODIES IN TBI}

The presence of long-term hypopituitarism after TBI, most frequently growth hormone $(\mathrm{GH})$ deficiency, has led researchers to investigate anti-hypothalamus antibodies (AHA), and antipituitary antibodies (APA), showing significant associations between these antibodies and head trauma $(116,117)$. High titers of APA and AHA in boxers were associated with hypopituitarism even after 5 years following TBI (118). The pathophysiological pathway of hypopituitarism and the role of autoimmunity in changes of hormone levels remains to be investigated.

$\mathrm{S} 100 \mathrm{~B}$ is a calcium-binding protein, present in perivascular astrocytes, but also in the CNS as an astrocyte-specific protein. $\mathrm{S} 100 \mathrm{~B}$ increases in the CSF and serum in correlation to the severity of traumatic brain injuries within the first hours to days $(115,119,120)$. In football players experiencing repetitive sub-concussive head hits, increased levels of S100B could be detected following individual games. Players with the most significant elevations of S100B had the highest titer of serum S100B autoantibodies at the end of a season. The level of S100B autoantibodies predicted MRI abnormalities and correlated with cognitive changes (121). S100B leakage into serum, could therefore have contributed to the development of autoantibodies after one season. MBP autoantibodies have been measured in the CSF of patients with a strong correlation to the severity of injury, which was measured by the Glasgow Coma Scale (GCS) (122). GFAP is an intermediate filament protein, predominantly found in the cytoskeleton of astrocytes. GFAP autoantibody levels increased by 7 days after TBI in humans (123) and were also found at a chronic time point 6 months post-injury (124). There were also higher plasma autoantibody levels against GFAP in patients with acute TBI and previous exposure to TBI compared to those without a previous history of TBI (124). Serum levels of autoantibodies against AMPA glutamate receptors (GluR1 subunit) and NMDA glutamate receptor (NR2A subunit) were examined in the serum from 60 children (7-16 years) with chronic posttraumatic headache at 6 and 12 months following trauma. Antibody titers to AMPA and largely NMDA were found to be higher when neurological symptoms persisted in children, which according to the authors was suggestive of hypoxic brain lesions, and evidence of hyperstimulation of NMDA glutamate receptors with greater permeability of the blood-brain-barrier (125). 
Taken together, elevated levels of brain-reactive autoantibodies can also be found following clinical TBI, in many cases correlating to the severity of injury and frequency of head impacts. The presence of autoantibodies does not provide evidence for an autoimmune disease. The pathogenic potential of brain-reactive antibodies, that could enter the brain through a compromised $\mathrm{BBB}$ remains to be explored.

\section{ADAPTIVE IMMUNITY IN TBI}

The specific role of neuroinflammation and autoantibodies in the recovery and neuropathology of TBI patients remains unclear. TBI induced neuropathology with accumulation of proteins such as amyloid beta $(\mathrm{A} \beta)$ has been associated with an increased risk of neurological diseases such as Alzheimer's disease (AD) and chronic traumatic encephalopathy (CTE) (126). The question whether chronic neuroinflammation causes this neuropathology or if it is a response to abnormal protein accumulation is not understood (105). In a recent study, concussion in adolescence was associated with an increased risk of multiple sclerosis (127). Experimental evidence points to a link between injury to the nervous system and myelin-antigen-specific $T$ cells, that have been shown to result in encephalomyelitis, if the genetic predisposition of an autoimmune disease is present (128). In one study reactive microglia were found in $28 \%$ of patients with traumatic brain injury with survival of $>1$ years and were linked to white matter degeneration and thinning of the corpus callosum (129). In another study, microglial activation was associated with more severe cognitive impairment years after trauma (130). Early $\mathrm{T}$ cell infiltration, peaking as early as $3-24 \mathrm{~h}$ after experimental TBI has been described in previous studies $(131,132)$. In another experimental study intracerebral injection of ovalbumin led to the infiltration and accumulation of ovalbumin-specific CD8+ T cells at sites of the cognate antigen. Following TBI, these activated antigen-specific CD8 $+\mathrm{T}$ cells were also attracted to sites of traumatic injury. This process could not be reduced by blocking CD154, which is presumed to be important for antigen-specific $\mathrm{T}$ cell activation, pointing to a presumably antigen-independent attraction to injury (133). In an experimental study of weightdrop induced closed head injury, Rag1 $1^{-} /^{-}$mice deficient of $\mathrm{B}$ and $\mathrm{T}$ lymphocytes, showed no difference regarding neurological and histological outcome and inflammatory mediators for up to 7 days following injury, compared with wild-type mice (134). In a similar study of weight-drop TBI, FTY720 was used to significantly reduce the numbers of circulating and brain infiltrating lymphocytes. There was no difference between BBB integrity, lesion size or functional outcome at 24 up to 7 days compared to untreated mice (135). This suggests that early T cell recruitment, which would presumably be antigen-independent, plays no role in early TBI up to 1 week. MBP autoreactive T cells were found in $40 \%$ of 10 patients 10 days after TBI using proliferation assays, but with no correlation to injury volume or severity in one study (136). The role of lymphocytes in TBI mediated inflammation and recovery, the question of antigenspecificity and activation pathways, especially in chronic models of TBI remain to be investigated.

\section{ADAPTIVE IMMUNITY IN OTHER CNS LESION MODELS}

In others models of injury to the CNS, there is evidence for a protective role of specific T cells. In optic nerve injury passively transferred $\mathrm{T}$ cells have been shown to accumulate at the injury site between 3 and 21 days irrespective of their antigen-specificity (MBP vs. ovalbumin) (137). The transfer of $\mathrm{T}$ cells specific to MBP to mice with optic nerve injury however promoted recovery, while this effect could not be observed with activated $\mathrm{T}$ cells to other non CNS-antigens (e.g., ovalbumin) (138). Mice that were actively immunized with myelin associated peptides such as MOG before injury to the optic nerve also had less degeneration of retinal ganglion cells (139). Similarly inducing tolerance to myelin proteins in neonates decreased the ability to a protective $\mathrm{T}$ cell mediated immune response to injury of myelinated axons in the CNS (140). Autoreactive T cells to myelin proteins such as MBP have also been found significantly proliferated in clinical and experimental spinal cord injury (SCI) (141-144) together with increased levels of serum autoantibodies against MAG and GM1 ganglioside in patients (145). In a model of facial nerve injury an expansion of myelin-antigen-specific $\mathrm{T}$ cells secreting IFN-y in cervical lymph nodes could be seen after 8 days (146). The transfer of anti-MBP T cells or the active immunization with MBP at the time and 1 week after contusion in an experimental rat model of SCI in both cases resulted in a significantly better functional outcome (147). In contrast, endogenous MBP-reactive lymphocytes, activated by experimental traumatic SCI contributed to tissue injury and impaired functional recovery (148). In a model of MBP (6368) peptide induced $E A E$, encephalitogenic $T$ cells using the TCR-BV8S2 ${ }^{+}$had a much higher proinflammatory cytokine to neurotrophin ratio than lymphoid cells bearing other TCRs. This would suggest that neuroprotection could be mediated by other non-MPB peptide-specific lymphoid cells $(149,150)$.

The question of the neuroprotective role of $\mathrm{T}$ cells and their antigen-specific activation was further addressed in a study with optic nerve crush injury and spinal cord injury. CD4+ $\mathrm{T}$ cells were activated independently of MHC II via damageassociated molecular mediators from CNS tissue that induced a population of neuroprotective IL-4 producing T cells. Recovery was promoted via neuronal IL-4 receptors that potentiated neurotrophin signaling (151). This suggests that antigenindependent pathways also play a role in neuroprotection after CNS injury. The question whether this protective mechanism is later enhanced by an autoimmune $\mathrm{T}$ cell response or if $\mathrm{T}$ cell infiltration could be increased through vaccination with an appropriate CNS self-antigen remains to be explored (139).

Recently, it was shown, that autoantibodies directed against different nervous system and systemic self-antigens, that increased within 5 days of human SCI, were already present in healthy subjects (152). Similar to stroke, this is an indication of a rapid augmentation of pre-existing naturally occurring autoantibodies. The role of autoreactive $\mathrm{B}$ cells has been investigated in SCI-induced autoimmunity $(101,102,153)$. SCI induces $\mathrm{B}$ cell proliferation, activation, and differentiation into IgG+ plasma cells. The formation of large B cell clusters 
expressing MHC II surrounded by CD3 $+\mathrm{T}$ cells and increased IgG synthesis after SCI resembles lymphoid follicles with B cell and $\mathrm{T}$ cell interactions (101). There is a delayed accumulation of B cells in the CSF and injured spinal cord with large deposits of antibody at sites of axon pathology and demyelination (102). Injection of circulating IgG antibodies purified from SCI mice in the spinal cord of uninjured animals causes consistent paralysis and pathology and B cell deficient mice have smaller lesions and better functional outcome after SCI (102).

\section{CONCLUSION}

Stroke and Traumatic Brain Injury (TBI) cause the release of brain-derived antigens into the circulation. In stroke, the detection of autoreactive $\mathrm{T}$ cells and the presence of autoantibodies to brain antigens suggests the possibility of autoimmunity. Inducing immune tolerance to brain antigens prior to experimental stroke shows mostly beneficial effects. Increased immunoreactivity to brain antigens and brain-reactive antibodies is associated with mostly detrimental effects, but some beneficial effects have also been shown. The early immunoreactivity to brain-antigens and detection of elevated levels of autoantibodies within hours to days after stroke onset, suggests the expansion of naturally occurring autoantibodies and pre-existing self-reactive T cells. The delayed presence of B cell and $\mathrm{T}$ cell clusters in stroke lesions with antibody production correlating to cognitive decline could be an indication of a detrimental adaptive immune response. The proinflammatory

\section{REFERENCES}

1. Iadecola C, Anrather J. The immunology of stroke: from mechanisms to translation. Nat Med. (2011) 17:796-808. doi: 10.1038/nm.2399

2. Corps KN, Roth TL, McGavern DB. Inflammation and neuroprotection in traumatic brain injury. JAMA Neurol. (2015) 72:355-62. doi: 10.1001/jamaneurol.2014.3558

3. Gelderblom M, Leypoldt F, Steinbach K, Behrens D, Choe CU, Siler DA, et al. Temporal and spatial dynamics of cerebral immune cell accumulation in stroke. Stroke. (2009) 40:1849-57. doi: 10.1161/STROKEAHA.108.534503

4. Das M, Mohapatra S, Mohapatra SS. New perspectives on central and peripheral immune responses to acute traumatic brain injury. $J$ Neuroinflamm. (2012) 9:236. doi: 10.1186/1742-2094-9-236

5. Planas AM, Gomez-Choco M, Urra X, Gorina R, Caballero M, Chamorro A. Brain-derived antigens in lymphoid tissue of patients with acute stroke. $J$ Immunol. (2012) 188:2156-63. doi: 10.4049/jimmunol.1102289

6. Wang $\mathrm{P}$, Zheng SG. Regulatory $\mathrm{T}$ cells and $\mathrm{B}$ cells: implication on autoimmune diseases. Int J Clin Exp Pathol. (2013) 6:2668-74.

7. Wang L, Wang FS, Gershwin ME. Human autoimmune diseases: a comprehensive update. J Intern Med. (2015) 278:369-95. doi: 10.1111/joim.12395

8. Kleinschnitz C, Schwab N, Kraft P, Hagedorn I, Dreykluft A, Schwarz T, et al. Early detrimental T-cell effects in experimental cerebral ischemia are neither related to adaptive immunity nor thrombus formation. Blood. (2010) 115:3835-42. doi: 10.1182/blood-2009-10-249078

9. Clarkson BD, Ling C, Shi Y, Harris MG, Rayasam A, Sun D, et al. $\mathrm{T}$ cell-derived interleukin (IL)-21 promotes brain injury following stroke in mice. J Exp Med. (2014) 211:595-604. doi: 10.1084/jem.20 131377

10. Brait VH, Arumugam TV, Drummond GR, Sobey CG. Importance of $\mathrm{T}$ lymphocytes in brain injury, immunodeficiency, and recovery microenvironment and infections following stroke could favor autoimmune responses to brain antigens breaking tolerance mechanisms. In TBI, the levels of brain antigens and brainreactive antibodies correlate with the severity of stroke and frequency of head impacts in most studies. If these antibodies are pathogenic, remains to be further explored. There is little evidence for the early role of T cells in early TBI and their long-term effects need to be investigated. In optic nerve crush injury and spinal cord lesion models, autoreactive $\mathrm{T}$ cells show protective effects, while antibody producing $B$ cells exacerbate spinal cord injury. Taken together, the existing data in favor of autoimmunity remains inconclusive. The effect of selfreactive autoantibodies is possibly small compared to other detrimental effects of the lesion itself and the induced local inflammation. Further studies are needed to understand the role of autoimmunity after brain lesions, investigating the generation, function and pathway of autoantibodies and the extent of their protective or detrimental role, with possible therapeutic implications.

\section{AUTHOR CONTRIBUTIONS}

EJ prepared and wrote the manuscript. TM wrote and supervised the manuscript.

\section{FUNDING}

Supported by a grant from the Schilling Foundation. after cerebral ischemia. J Cerebr Blood Flow Metab. (2012) 32:598-611. doi: $10.1038 /$ jcbfm.2012.6

11. Ludewig P, Sedlacik J, Gelderblom M, Bernreuther C, Korkusuz Y, Wagener $\mathrm{C}$, et al. Carcinoembryonic antigen-related cell adhesion molecule 1 inhibits MMP-9-mediated blood-brain-barrier breakdown in a mouse model for ischemic stroke. Circ Res. (2013) 113:1013-22. doi: 10.1161/CIRCRESAHA.113.301207

12. Jiang X, Andjelkovic AV, Zhu L, Yang T, Bennett MVL, Chen J, et al. Bloodbrain barrier dysfunction and recovery after ischemic stroke. Prog Neurobiol. (2018) 163-164:144-71. doi: 10.1016/j.pneurobio.2017.10.001

13. Iliff JJ, Wang M, Liao Y, Plogg BA, Peng W, Gundersen GA, et al. A paravascular pathway facilitates CSF flow through the brain parenchyma and the clearance of interstitial solutes, including amyloid $\beta$. Sci Transl Med. (2012) 4:147ral1. doi: 10.1126/scitranslmed.3003748

14. Ma Q, Ineichen BV, Detmar M, Proulx ST. Outflow of cerebrospinal fluid is predominantly through lymphatic vessels and is reduced in aged mice. Nat Commun. (2017) 8:1434. doi: 10.1038/s41467-017-01484-6

15. Louveau A, Smirnov I, Keyes TJ, Eccles JD, Rouhani SJ, Peske JD, et al. Structural and functional features of central nervous system lymphatic vessels. Nature. (2015) 523:337. doi: 10.1038/nature14432

16. Verheggen ICM, Van Boxtel MPJ, Verhey FRJ, Jansen JFA, Backes WH. Interaction between blood-brain barrier and glymphatic system in solute clearance. Neurosci Biobehav Rev. (2018) 90:26-33. doi: $10.1016 / j . n e u b i o r e v .2018 .03 .028$

17. Felger JC, Abe T, Kaunzner UW, Gottfried-Blackmore A, Gal-Toth J, McEwen BS, et al. Brain dendritic cells in ischemic stroke: time course, activation state, and origin. Brain Behav Immun. (2010) 24:724-37. doi: 10.1016/j.bbi.2009.11.002

18. Ludewig P, Gallizioli M, Urra X, Behr S, Brait VH, Gelderblom M, et al. Dendritic cells in brain diseases. Biochim Biophys Acta. (2016) 1862:352-67. doi: 10.1016/j.bbadis.2015.11.003 
19. Liesz A, Karcher S, Veltkamp R. Spectratype analysis of clonal T cell expansion in murine experimental stroke. J Neuroimmunol. (2013) 257:4652. doi: 10.1016/j.jneuroim.2013.01.013

20. de Vos AF, van Meurs M, Brok HP, Boven LA, Hintzen RQ, van der Valk P, et al. Transfer of central nervous system autoantigens and presentation in secondary lymphoid organs. J Immunol. (2002) 169:5415-23. doi: 10.4049/jimmunol.169.10.5415

21. Bartholomaus I, Kawakami N, Odoardi F, Schlager C, Miljkovic D, Ellwart JW, et al. Effector $\mathrm{T}$ cell interactions with meningeal vascular structures in nascent autoimmune CNS lesions. Nature. (2009) 462:94-8. doi: $10.1038 /$ nature 08478

22. Miró-Mur F, Urra X, Gallizioli M, Chamorro A, Planas AM. Antigen presentation after stroke. Neurotherapeutics.(2016) 13:719-28. doi: 10.1007/s13311-016-0469-8

23. Banchereau J, Steinman RM. Dendritic cells and the control of immunity. Nature. (1998) 392:245-52. doi: 10.1038/32588

24. Garza KM, Chan SM, Suri R, Nguyen LT, Odermatt B, Schoenberger SP, et al. Role of antigen-presenting cells in mediating tolerance and autoimmunity. $J$ Exp Med. (2000) 191:2021-7. doi: 10.1084/jem.191.11.2021

25. Benakis C, Llovera G, Liesz A. The meningeal and choroidal infiltration routes for leukocytes in stroke. Ther Adv Neurol Disord. 11:1756286418783708-1756286418783708. doi: 10.1177/1756286418783708

26. Audiger C, Rahman MJ, Yun TJ, Tarbell KV, Lesage S. The importance of dendritic cells in maintaining immune tolerance. J Immunol. (2017) 198:2223-31. doi: 10.4049/jimmunol.1601629

27. Gelderblom M, Gallizioli M, Ludewig P, Thom V, Arunachalam P, Rissiek B, et al. IL-23 (Interleukin-23)-producing conventional dendritic cells control the detrimental IL-17 (interleukin-17) response in Stroke. Stroke. (2018) 49:155-64. doi: 10.1161/STROKEAHA.117.019101

28. Almolda B, Gonzalez B, Castellano B. Antigen presentation in EAE: role of microglia, macrophages and dendritic cells. Front Biosci. (2011) 16:1157-71. doi: $10.2741 / 3781$

29. Nuyts AH, Lee WP, Bashir-Dar R, Berneman ZN, Cools N. Dendritic cells in multiple sclerosis: key players in the immunopathogenesis, key players for new cellular immunotherapies? Mult Scler. (2013) 19:995-1002. doi: $10.1177 / 1352458512473189$

30. Bailey SL, Schreiner B, McMahon EJ, Miller SD. CNS myeloid DCs presenting endogenous myelin peptides 'preferentially' polarize CD4+ $\mathrm{T}(\mathrm{H})-17$ cells in relapsing EAE. Nat Immunol. (2007) 8:172-80. doi: $10.1038 /$ ni1 1430

31. Gülke E, Gelderblom M, Magnus T. Danger signals in stroke and their role on microglia activation after ischemia. Ther Adv Neurol Disord. 11:1756286418774254. doi: 10.1177/1756286418774254

32. Luo C, Jian C, Liao Y, Huang Q, Wu Y, Liu X, et al. The role of microglia in multiple sclerosis. Neuropsychiatr Dis Treat. (2017) 13:1661-7. doi: 10.2147/NDT.S140634

33. Almolda B, Gonzalez B, Castellano B. Activated microglial cells acquire an immature dendritic cell phenotype and may terminate the immune response in an acute model of EAE. J Neuroimmunol. (2010) 223:39-54. doi: 10.1016/j.jneuroim.2010.03.021

34. Jin WN, Gonzales R, Feng Y, Wood K, Chai Z, Dong JF, et al. Brain ischemia induces diversified neuroantigen-specific $T$-cell responses that exacerbate brain injury. Stroke. (2018) 49:1471-8. doi: 10.1161/STROKEAHA.118.020203

35. Gronberg NV, Johansen FF, Kristiansen U, Hasseldam H. Leukocyte infiltration in experimental stroke. J Neuroinflammation. (2013) 10:115. doi: 10.1186/1742-2094-10-115

36. Chu HX, Kim HA, Lee S, Moore JP, Chan CT, Vinh A, et al. Immune cell infiltration in malignant middle cerebral artery infarction: comparison with transient cerebral ischemia. J Cereb Blood Flow Metab. (2014) 34:450-9. doi: $10.1038 / \mathrm{jcbfm} .2013 .217$

37. Mracsko E, Javidi E, Na SY, Kahn A, Liesz A, Veltkamp R. Leukocyte invasion of the brain after experimental intracerebral hemorrhage in mice. Stroke. (2014) 45:2107-14. doi: 10.1161/STROKEAHA.114.005801

38. Stevens SL, Bao J, Hollis J, Lessov NS, Clark WM, Stenzel-Poore MP. The use of flow cytometry to evaluate temporal changes in inflammatory cells following focal cerebral ischemia in mice. Brain Res. (2002) 932:110-9. doi: $10.1016 /$ S0006-8993(02)02292-8
39. Liesz A, Zhou W, Mracsk,ó É, Karcher S, Bauer H, Schwarting S, et al. Inhibition of lymphocyte trafficking shields the brain against deleterious neuroinflammation after stroke. Brain. (2011) 134:704-720. doi: 10.1093/brain/awr008

40. Doyle KP, Quach LN, Sole M, Axtell RC, Nguyen TV, Soler-Llavina GJ, et al. B-lymphocyte-mediated delayed cognitive impairment following stroke. $J$ Neurosci. (2015) 35:2133-45. doi: 10.1523/JNEUROSCI.4098-14.2015

41. Gill D, Veltkamp R. Dynamics of T cell responses after stroke. Curr Opin Pharmacol. (2016) 26:26-32. doi: 10.1016/j.coph.2015.09.009

42. Yilmaz G, Arumugam TV, Stokes KY, Granger DN. Role of T lymphocytes and interferon-gamma in ischemic stroke. Circulation. (2006) 113:2105-12. doi: 10.1161/CIRCULATIONAHA.105.593046

43. Liesz A, Suri-Payer E, Veltkamp C, Doerr H, Sommer C, Rivest S, et al. Regulatory $\mathrm{T}$ cells are key cerebroprotective immunomodulators in acute experimental stroke. Nat Med. (2009) 15:192-9. doi: 10.1038/nm.1927 .

44. Shichita T, Sugiyama Y, Ooboshi H, Sugimori H, Nakagawa R, Takada I, et al. Pivotal role of cerebral interleukin-17-producing $\gamma \delta \mathrm{T}$ cells in the delayed phase of ischemic brain injury. Nat Med. (2009) 15:946. doi: 10.1038/nm.1999

45. Mracsko E, Liesz A, Stojanovic A, Lou WP, Osswald M, Zhou W, et al. Antigen dependently activated cluster of differentiation 8-positive T cells cause perforin-mediated neurotoxicity in experimental stroke. $J$ Neurosci. (2014) 34:16784-95. doi: 10.1523/JNEUROSCI.1867-14.2014

46. Ortega SB, Noorbhai I, Poinsatte K, Kong X, Anderson A, Monson NL, et al. Stroke induces a rapid adaptive autoimmune response to novel neuronal antigens. Discov Med. (2015) 19:381-92.

47. Dominguez-Villar M, Hafler DA. Regulatory T cells in autoimmune disease. Nat Immunol. (2018) 19:665-73. doi: 10.1038/s41590-018-0120-4

48. Liesz A, Suri-Payer E, Veltkamp C, Doerr H, Sommer C, Rivest S, et al. Regulatory $\mathrm{T}$ cells are key cerebroprotective immunomodulators in acute experimental stroke. Nat Med. (2009) 15:192-9. doi: 10.1038/nm.1927

49. Stubbe T, Ebner F, Richter D, Engel O, Randolf Engel O, Klehmet J, et al. Regulatory $\mathrm{T}$ cells accumulate and proliferate in the ischemic hemisphere for up to 30 days after MCAO. J Cereb Blood Flow Metab. (2013) 33:37-47. doi: $10.1038 / \mathrm{jcbfm} .2012 .128$

50. Liesz A, Hu X, Kleinschnitz C, Offner H. Functional role of regulatory lymphocytes in stroke: facts and controversies. Stroke. (2015) 46:1422-30. doi: 10.1161/STROKEAHA.114.008608

51. Offner H, Subramanian S, Parker SM, Wang C, Afentoulis ME, Lewis A, et al. Splenic atrophy in experimental stroke is accompanied by increased regulatory T cells and circulating macrophages. J Immunol. (2006) 176:652331. doi: 10.4049/jimmunol.176.11.6523

52. Kleinschnitz C, Kraft P, Dreykluft A, Hagedorn I, Göbel K, Schuhmann MK, et al. Regulatory $\mathrm{T}$ cells are strong promoters of acute ischemic stroke in mice by inducing dysfunction of the cerebral microvasculature. Blood. (2013) 121:679-91. doi: 10.1182/blood-2012-04-426734

53. Ito M, Komai K, Mise-Omata S, Iizuka-Koga M, Noguchi $Y$, Kondo T, et al. Brain regulatory $\mathrm{T}$ cells suppress astrogliosis and potentiate neurological recovery. Nature. (2019) 565:246-50. doi: 10.1038/s41586-018-0824-5

54. Chen Y, Ruetzler C, Pandipati S, Spatz M, McCarron RM, Becker K, et al. Mucosal tolerance to E-selectin provides cell-mediated protection against ischemic brain injury. Proc Natl Acad Sci USA. (2003) 100:15107-12. doi: 10.1073/pnas.2436538100

55. Gee JM, Kalil A, Thullbery M, Becker KJ. Induction of immunologic tolerance to myelin basic protein prevents central nervous system autoimmunity and improves outcome after stroke. Stroke. (2008) 39:157582. doi: 10.1161/STROKEAHA.107.501486

56. Ishibashi S, Maric D, Mou Y, Ohtani R, Ruetzler C, Hallenbeck JM. Mucosal tolerance to E-selectin promotes the survival of newly generated neuroblasts via regulatory T-cell induction after stroke in spontaneously hypertensive rats. J Cereb Blood Flow Metab. (2009) 29:60620. doi: $10.1038 / \mathrm{jcbfm} .2008 .153$

57. Wang WZ, Olsson T, Kostulas V, Hojeberg B, Ekre HP, Link H. Myelin antigen reactive $\mathrm{T}$ cells in cerebrovascular diseases. Clin Exp Immunol. (1992) 88:157-62. doi: 10.1111/j.1365-2249.1992.tb03056.x

58. Jauch EC, Lindsell C, Broderick J, Fagan SC, Tilley BC, Levine SR. Association of serial biochemical markers with acute ischemic stroke: the national institute of neurological disorders and stroke recombinant 
tissue plasminogen activator stroke study. Stroke. (2006) 37:2508-13. doi: 10.1161/01.STR.0000242290.01174.9e

59. Walsh KP, Mills KH. Dendritic cells and other innate determinants of $\mathrm{T}$ helper cell polarisation. Trends Immunol. (2013) 34:521-30. doi: 10.1016/j.it.2013.07.006

60. Becker KJ, Kindrick DL, Lester MP, Shea C, Ye ZC. Sensitization to brain antigens after stroke is augmented by lipopolysaccharide. J Cereb Blood Flow Metab. (2005) 25:1634-44. doi: 10.1038/sj.jcbfm.9600160

61. Frenkel D, Huang Z, Maron R, Koldzic DN, Moskowitz MA, Weiner HL. Neuroprotection by IL-10-producing MOG CD4+ T cells following ischemic stroke. J Neurol Sci. (2005) 233:125-32. doi: 10.1016/j.jns.2005.03.022

62. Zierath D, Thullbery M, Hadwin J, Gee JM, Savos A, Kalil A, et al. CNS immune responses following experimental stroke. Neurocrit Care. (2010) 12:274-84. doi: 10.1007/s12028-009-9270-4

63. Zierath D, Schulze J, Kunze A, Drogomiretskiy O, Nhan D, Jaspers B, et al. The immunologic profile of adoptively transferred lymphocytes influences stroke outcome of recipients. J Neuroimmunol. (2013) 263:28-34. doi: 10.1016/j.jneuroim.2013.07.014

64. Ren X, Akiyoshi K, Grafe MR, Vandenbark AA, Hurn PD, Herson PS, et al. Myelin specific cells infiltrate MCAO lesions and exacerbate stroke severity. Metab Brain Dis. (2012) 27:7-15. doi: 10.1007/s11011-011-9267-5

65. Zierath D, Hadwin J, Savos A, Carter KT, Kunze A, Becker KJ. Anamnestic recall of stroke related deficits - an animal model. Stroke. (2010) 41:2653-60. doi: 10.1161/STROKEAHA.110.592865

66. Buttini M, Limonta S, Boddeke HW. Peripheral administration of lipopolysaccharide induces activation of microglial cells in rat brain. Neurochem Int. (1996) 29:25-35. doi: 10.1016/0197-0186(95)00141-7

67. Zierath D, Kunze A, Fecteau L, Becker K. Promiscuity of autoimmune responses to MBP after stroke. J Neuroimmunol. (2015) 285:101-5. doi: 10.1016/j.jneuroim.2015.05.024

68. Becker KJ, McCarron RM, Ruetzler C, Laban O, Sternberg E, Flanders $\mathrm{KC}$, et al. Immunologic tolerance to myelin basic protein decreases stroke size after transient focal cerebral ischemia. Proc Natl Acad Sci USA. (1997) 94:10873-8. doi: 10.1073/pnas.94.20.10873

69. Becker K, Kindrick D, McCarron R, Hallenbeck J, Winn R. Adoptive transfer of myelin basic protein-tolerized splenocytes to naive animals reduces infarct size: a role for lymphocytes in ischemic brain injury? Stroke. (2003) 34:180915. doi: 10.1161/01.STR.0000078308.77727.EA

70. Subramanian S, Zhang B, Kosaka Y, Burrows GG, Grafe MR, Vandenbark $\mathrm{AA}$, et al. Recombinant $\mathrm{T}$ cell receptor ligand treats experimental stroke. Stroke. (2009) 40:2539-45. doi: 10.1161/STROKEAHA.108.543991

71. Huan J, Subramanian S, Jones R, Rich C, Link J, Mooney J, et al. Monomeric recombinant TCR ligand reduces relapse rate and severity of experimental autoimmune encephalomyelitis in SJL/J mice through cytokine switch. $J$ Immunol. (2004) 172:4556-66. doi: 10.4049/jimmunol.172.7.4556

72. Becker KJ, Kalil AJ, Tanzi P, Zierath DK, Savos AV, Gee JM, et al. Autoimmune responses to the brain after stroke are associated with worse outcome. Stroke. (2011) 42:2763-9. doi: 10.1161/STROKEAHA.111.619593

73. Becker K. Autoimmune responses to brain following stroke. Transl Stroke Res. (2012) 3:310-7. doi: 10.1007/s12975-012-0154-0

74. Klehmet J, Hoffmann S, Walter G, Meisel C, Meisel A. Stroke induces specific alteration of $\mathrm{T}$ memory compartment controlling auto-reactive CNS antigen-specific T cell responses. J Neurol Sci. (2016) 368:77-83. doi: 10.1016/j.jns.2016.06.039

75. Romer C, Engel O, Winek K, Hochmeister S, Zhang T, Royl G, et al. Blocking stroke-induced immunodeficiency increases CNS antigen-specific autoreactivity but does not worsen functional outcome after experimental stroke. J Neurosci. (2015) 35:7777-94. doi: 10.1523/JNEUROSCI.1532-14.2015

76. Chen Y, Kuchroo VK, Inobe J, Hafler DA, Weiner HL. Regulatory $\mathrm{T}$ cell clones induced by oral tolerance: suppression of autoimmune encephalomyelitis. Science. (1994) 265:1237-40. doi: $10.1126 /$ science. 7520605

77. LeBien TW, Tedder TF. B lymphocytes: how they develop and function. Blood. (2008) 112:1570-80. doi: 10.1182/blood-2008-02-078071

78. Hoffman W, Lakkis FG, Chalasani G. B cells, antibodies, and more. Clin J Am Soc Nephrol. (2016) 11:137-54. doi: 10.2215/CJN.09430915
79. Levin EC, Acharya NK, Han M, Zavareh SB, Sedeyn JC, Venkataraman V, et al. Brain-reactive autoantibodies are nearly ubiquitous in human sera and may be linked to pathology in the context of blood-brain barrier breakdown. Brain Res. (2010) 1345:221-32. doi: 10.1016/j.brainres.2010.05.038

80. Hwang JK, Alt FW, Yeap LS. Related mechanisms of antibody somatic hypermutation and class switch recombination. Microbiol Spectr. (2015) 3:MDNA3-2014. doi: 10.1128/microbiolspec.MDNA3-0037-2014

81. Blum JS, Wearsch PA, Cresswell P. Pathways of antigen processing. Annu Rev Immunol. (2013) 31:443-73. doi: 10.1146/annurev-immunol-032712-095910

82. Liesz A, Dalpke A, Mracsko E, Antoine DJ, Roth S, Zhou W, et al. DAMP signaling is a key pathway inducing immune modulation after brain injury. $J$ Neurosci. (2015) 35:583-98. doi: 10.1523/JNEUROSCI.2439-14.2015

83. Doyle KP, Buckwalter MS. Does B lymphocyte-mediated autoimmunity contribute to post-stroke dementia? Brain Behav Immun. (2017) 64:1-8. doi: 10.1016/j.bbi.2016.08.009

84. Shi K, Wood K, Shi FD, Wang X, Liu Q. Stroke-induced immunosuppression and poststroke infection. Stroke Vasc Neurol. (2018) 3:34-41. doi: 10.1136/svn-2017-000123

85. Rostrom B, Link B. Oligoclonal immunoglobulins in cerebrospinal fluid in acute cerebrovascular disease. Neurology. (1981) 31:590-6. doi: 10.1212/WNL.31.5.590

86. Tsementzis SA, Chao SW, Hitchcock ER, Gill JS, Beevers DG. Oligoclonal immunoglobulin $G$ in acute subarachnoid hemorrhage and stroke. Neurology. (1986) 36:395-7. doi: 10.1212/WNL.36.3.395

87. Prüss H, Iggena D, Baldinger T, Prinz V, Meisel A, Endres M, et al. Evidence of intrathecal immunoglobulin synthesis in stroke: a cohort study. Arch Neurol. (2012) 69:714-7. doi: 10.1001/archneurol.2011.3252

88. Bornstein NM, Aronovich B, Korczyn AD, Shavit S, Michaelson DM, Chapman J. Antibodies to brain antigens following stroke. Neurology. (2001) 56:529-30. doi: 10.1212/WNL.56.4.529

89. Barry H, Byrne S, Barrett E, Murphy KC, Cotter DR. Anti-N-methyl-daspartate receptor encephalitis: review of clinical presentation, diagnosis and treatment. BJPsych Bull. (2015) 39:19-23. doi: 10.1192/pb.bp.113.045518

90. Dambinova SA, Khounteev GA, Izykenova GA, Zavolokov IG, Ilyukhina AY, Skoromets AA. Blood test detecting autoantibodies to N-methyl-D-aspartate neuroreceptors for evaluation of patients with transient ischemic attack and stroke. Clin Chem. (2003) 49:1752-62. doi: 10.1373/49.10.1752

91. Bokesch PM, Izykenova GA, Justice JB, Easley KA, Dambinova SA. NMDA receptor antibodies predict adverse neurological outcome after cardiac surgery in high-risk patients. Stroke. (2006) 37:1432-6. doi: 10.1161/01.STR.0000221295.14547.c8

92. Weissman JD, Khunteev GA, Heath R, Dambinova SA. NR2 antibodies: risk assessment of transient ischemic attack (TIA)/stroke in patients with history of isolated and multiple cerebrovascular events. J Neurol Sci. (2011) 300:97-102. doi: 10.1016/j.jns.2010.09.023

93. Kalev-Zylinska ML, Symes W, Little KCE, Sun P, Wen D, Qiao L, et al. Stroke patients develop antibodies that react with components of nmda receptor subunit 1 in proportion to lesion size. Stroke. (2013) 44:2212-9. doi: 10.1161/STROKEAHA.113.001235

94. Hammer C, Stepniak B, Schneider A, Papiol S, Tantra M, Begemann M, et al. Neuropsychiatric disease relevance of circulating anti-NMDA receptor autoantibodies depends on blood-brain barrier integrity. Mol Psychiatry. (2014) 19:1143-9. doi: 10.1038/mp.2013.110

95. Elvington A, Atkinson C, Kulik L, Zhu H, Yu J, Kindy MS, et al. Pathogenic natural antibodies propagate cerebral injury following ischemic stroke in mice. J Immunol. (2012) 188:1460-8. doi: 10.4049/jimmunol.1102132

96. Chen Y, Bodhankar S, Murphy SJ, Vandenbark AA, Alkayed NJ, Offner H. Intrastriatal B-cell administration limits infarct size after stroke in B-cell deficient mice. Metab Brain Dis. (2012) 27:487-93. doi: 10.1007/s11011-012-9317-7

97. Ren X, Akiyoshi K, Dziennis S, Vandenbark AA, Herson PS, Hurn $\mathrm{PD}$, et al. Regulatory B cells limit CNS inflammation and neurologic deficits in murine experimental stroke. J Neurosci. (2011) 31:8556-63. doi: 10.1523/JNEUROSCI.1623-11.2011

98. Bodhankar S, Chen Y, Vandenbark AA, Murphy SJ, Offner $H$. IL-10-producing B-cells limit CNS inflammation and infarct volume in experimental stroke. Metab Brain Dis. (2013) 28:375-86. doi: 10.1007/s11011-013-9413-3 
99. Becker KJ, Tanzi P, Zierath D, Buckwalter MS. Antibodies to myelin basic protein are associated with cognitive decline after stroke. J Neuroimmunol. (2016) 295-296:9-11. doi: 10.1016/j.jneuroim.2016.04.001

100. Matsushita T, Yanaba K, Bouaziz JD, Fujimoto M, Tedder TF. Regulatory $\mathrm{B}$ cells inhibit EAE initiation in mice while other $\mathrm{B}$ cells promote disease progression. J Clin Invest. (2008) 118:3420-30. doi: 10.1172/JCI 36030

101. Ankeny DP, Lucin KM, Sanders VM, McGaughy VM, Popovich PG. Spinal cord injury triggers systemic autoimmunity: evidence for chronic B lymphocyte activation and lupus-like autoantibody synthesis. J Neurochem. (2006) 99:1073-87. doi: 10.1111/j.1471-4159.2006.04147.x

102. Ankeny DP, Guan Z, Popovich PG. B cells produce pathogenic antibodies and impair recovery after spinal cord injury in mice. J Clin Invest. (2009) 119:2990-9. doi: 10.1172/JCI39780

103. Yeoh S, Bell ED, Monson KL. Distribution of blood-brain barrier disruption in primary blast injury. Ann Biomed Eng. (2013) 41:2206-14. doi: 10.1007/s10439-013-0805-7

104. Daneshvar DH, Goldstein LE, Kiernan PT, Stein TD, McKee AC. Posttraumatic neurodegeneration and chronic traumatic encephalopathy. Mol Cell Neurosci. (2015) 66:81-90. doi: 10.1016/j.mcn.2015.03.007

105. Simon DW, McGeachy MJ, Bayir H, Clark RSB, Loane DJ, Kochanek PM. The far-reaching scope of neuroinflammation after traumatic brain injury. Nat Rev Neurol. (2017) 13:171-91. doi: 10.1038/nrneurol.2017.13

106. Dorsett CR, McGuire JL, DePasquale EA, Gardner AE, Floyd CL, McCullumsmith RE. Glutamate neurotransmission in rodent models of traumatic brain injury. J Neurotrauma. (2017) 34:263-72. doi: $10.1089 /$ neu. 2015.4373

107. Anthonymuthu TS, Kenny EM, and Bayir H. Therapies targeting lipid peroxidation in traumatic brain injury. Brain Res. (2016) 1640:57-76. doi: 10.1016/j.brainres.2016.02.006

108. Jassam YN, Izzy S, Whalen M, McGavern DB, El Khoury J. Neuroimmunology of traumatic brain injury: time for a paradigm shift. Neuron. (2017) 95:1246-65. doi: 10.1016/j.neuron.2017.07.010

109. Siman R, Toraskar N, Dang A, McNeil E, McGarvey M, Plaum J, et al. A panel of neuron-enriched proteins as markers for traumatic brain injury in humans. J Neurotrauma. (2009) 26:1867-77. doi: 10.1089/neu.2009.0882

110. Mondello S, Robicsek SA, Gabrielli A, Brophy GM, Papa L, Tepas J, et al. $\alpha$ II-spectrin breakdown products (SBDPs): diagnosis and outcome in severe traumatic brain injury patients. J Neurotrauma. (2010) 27:1203-13. doi: 10.1089/neu.2010.1278

111. Hajduková L, Sobek O, Prchalová D, Bílková Z, Koudelková M, Lukášková J, et al. Biomarkers of brain damage: S100B and NSE concentrations in cerebrospinal fluid-a normative study. BioMed Res Int. (2015) 2015: 379071. doi: 10.1155/2015/379071

112. Mondello S, Kobeissy F, Vestri A, Hayes RL, Kochanek PM, Berger RP. Serum concentrations of ubiquitin C-terminal hydrolase-L1 and glial fibrillary acidic protein after pediatric traumatic brain injury. Sci Rep. (2016) 6:28203. doi: $10.1038 /$ srep28203

113. Papa L, Brophy GM, Welch RD, Lewis LM, Braga CF, Tan CN, et al. Time course and diagnostic accuracy of glial and neuronal blood biomarkers gfap and uch-11 in a large cohort of trauma patients with and without mild traumatic brain injury. JAMA Neurol. (2016) 73:551-60. doi: 10.1001/jamaneurol.2016.0039

114. Takala RS, Posti JP, Runtti H, Newcombe VF, Outtrim J, Katila AJ, et al. Glial fibrillary acidic protein and ubiquitin C-terminal hydrolase-L1 as outcome predictors in traumatic brain injury. World Neurosurg. (2016) 87:8-20. doi: 10.1016/j.wneu.2015.10.066

115. Thelin EP, Jeppsson E, Frostell A, Svensson M, Mondello S, Bellander B-M, et al. Utility of neuron-specific enolase in traumatic brain injury; relations to S100B levels, outcome, and extracranial injury severity. Crit Care. (2016) 20:285. doi: 10.1186/s13054-016-1450-y

116. Tanriverdi F, De Bellis A, Bizzarro A, Sinisi AA, Bellastella G, Pane E, et al. Antipituitary antibodies after traumatic brain injury: is head trauma-induced pituitary dysfunction associated with autoimmunity? Eur $J$ Endocrinol. (2008) 159:7-13. doi: 10.1530/EJE-08-0050

117. Tanriverdi F, De Bellis A, Battaglia M, Bellastella G, Bizzarro A, Sinisi AA, et al. Investigation of antihypothalamus and antipituitary antibodies in amateur boxers: is chronic repetitive head trauma-induced pituitary dysfunction associated with autoimmunity? Eur J Endocrinol. (2010) 162:861-7. doi: 10.1530/EJE-09-1024

118. Tanriverdi F, De Bellis A, Ulutabanca H, Bizzarro A, Sinisi AA, Bellastella $\mathrm{G}$, et al. A five year prospective investigation of anterior pituitary function after traumatic brain injury: is hypopituitarism long-term after head trauma associated with autoimmunity? J Neurotrauma. (2013) 30:1426-33. doi: 10.1089/neu.2012.2752

119. Goyal A, Failla MD, Niyonkuru C, Amin K, Fabio A, Berger RP, et al. $\mathrm{S} 100 \mathrm{~b}$ as a prognostic biomarker in outcome prediction for patients with severe traumatic brain injury. J Neurotrauma. (2013) 30:946-57. doi: 10.1089/neu.2012.2579

120. Thelin EP, Nelson DW, Bellander B-M. A review of the clinical utility of serum S100B protein levels in the assessment of traumatic brain injury. Acta Neurochirurg. (2017) 159:209-25. doi: 10.1007/s00701-016-3046-3

121. Marchi N, Bazarian JJ, Puvenna V, Janigro M, Ghosh C, Zhong J, et al. Consequences of repeated blood-brain barrier disruption in football players. PLoS ONE. (2013) 8:e56805. doi: 10.1371/journal.pone.0056805

122. Ngankam L, Kazantseva NV, Gerasimova MM. [Immunological markers of severity and outcome of traumatic brain injury]. Zh Nevrol Psikhiatr Im S S Korsakova. (2011) 111:61-5.

123. Zhang Z, Zoltewicz JS, Mondello S, Newsom KJ, Yang Z, Yang B, et al. Human traumatic brain injury induces autoantibody response against glial fibrillary acidic protein and its breakdown products. PLoS ONE. (2014) 9:e92698. doi: 10.1371/journal.pone.0092698

124. Wang KK, Yang Z, Yue JK, Zhang Z, Winkler EA, Puccio AM, et al. Plasma anti-glial fibrillary acidic protein autoantibody levels during the acute and chronic phases of traumatic brain injury: a transforming research and clinical knowledge in traumatic brain injury pilot study. J Neurotrauma. (2016) 33:1270-7. doi: 10.1089/neu.2015.3881

125. Goryunova AV, Bazarnaya NA, Sorokina EG, Semenova NY, Globa OV, Semenova ZhB, et al. Glutamate receptor autoantibody concentrations in children with chronic post-traumatic headache. Neurosci Behav Physiol. (2007) 37:761-4. doi: 10.1007/s11055-007-0079-3

126. Shively S, Scher AI, Perl DP, Diaz-Arrastia R. Dementia resulting from traumatic brain injury: what is the pathology? Arch Neurol. (2012) 69:124551. doi: 10.1001/archneurol.2011.3747

127. Montgomery S, Hiyoshi A, Burkill S, Alfredsson L, Bahmanyar S, Olsson T. Concussion in adolescence and risk of multiple sclerosis. Ann Neurol. (2017) 82:554-61. doi: 10.1002/ana.25036

128. Swanberg M, Lidman O, Padyukov L, Eriksson P, Akesson E, Jagodic M, et al. MHC2TA is associated with differential MHC molecule expression and susceptibility to rheumatoid arthritis, multiple sclerosis and myocardial infarction. Nat Genet. (2005) 37:486-94. doi: 10.1038/ng1544

129. Johnson VE, Stewart JE, Begbie FD, Trojanowski JQ, Smith DH, Stewart W. Inflammation and white matter degeneration persist for years after a single traumatic brain injury. Brain. (2013) 136:28-42. doi: 10.1093/brain/aws322

130. Ramlackhansingh AF, Brooks DJ, Greenwood RJ, Bose SK, Turkheimer $\mathrm{FE}$, Kinnunen $\mathrm{KM}$, et al. Inflammation after trauma: microglial activation and traumatic brain injury. Ann Neurol. (2011) 70:374-83. doi: 10.1002/ana.22455

131. Clausen F, Lorant T, Lewen A, Hillered L. T lymphocyte trafficking: a novel target for neuroprotection in traumatic brain injury. J Neurotrauma. (2007) 24:1295-307. doi: 10.1089/neu.2006.0258

132. Czigner A, Mihaly A, Farkas O, Buki A, Krisztin-Peva B, Dobo E, et al. Kinetics of the cellular immune response following closed head injury. Acta Neurochir. (2007) 149:281-9. doi: 10.1007/s00701-006-1095-8

133. Ling C, Sandor M, Suresh M, Fabry Z. Traumatic injury and the presence of antigen differentially contribute to T-cell recruitment in the CNS. J Neurosci. (2006) 26:731-41. doi: 10.1523/JNEUROSCI.3502-05.2006

134. Weckbach S, Neher M, Losacco JT, Bolden AL, Kulik L, Flierl MA, et al. Challenging the role of adaptive immunity in neurotrauma: Rag1(-/-) mice lacking mature $\mathrm{B}$ and $\mathrm{T}$ cells do not show neuroprotection after closed head injury. J Neurotrauma. (2012) 29:1233-42. doi: 10.1089/neu.20 11.2169

135. Mencl S, Hennig N, Hopp S, Schuhmann MK, Albert-Weissenberger C, Sirén AL, et al. FTY720 does not protect from traumatic brain injury in mice despite reducing posttraumatic inflammation. J Neuroimmunol. (2014) 274:125-31. doi: 10.1016/j.jneuroim.2014.07.010 
136. Cox AL, Coles AJ, Nortje J, Bradley PG, Chatfield DA, Thompson SJ, et al. An investigation of auto-reactivity after head injury. J Neuroimmunol. (2006) 174:180-6. doi: 10.1016/j.jneuroim.2006.01.007

137. Hirschberg DL, Moalem G, He J, Mor F, Cohen IR, Schwartz M. Accumulation of passively transferred primed $\mathrm{T}$ cells independently of their antigen specificity following central nervous system trauma. J Neuroimmunol. (1998) 89:88-96. doi: 10.1016/S0165-5728(98) 00118-0

138. Moalem G, Leibowitz-Amit R, Yoles E, Mor F, Cohen IR, Schwartz M. Autoimmune $\mathrm{T}$ cells protect neurons from secondary degeneration after central nervous system axotomy. Nat Med. (1999) 5:49. doi: 10.1038/4734

139. Fisher J, Levkovitch-Verbin H, Schori H, Yoles E, Butovsky O, Kaye JF, et al. Vaccination for neuroprotection in the mouse optic nerve: implications for optic neuropathies. J Neurosci. (2001) 21:136-42. doi: 10.1523/JNEUROSCI.21-01-00136.2001

140. Kipnis J, Mizrahi T, Hauben E, Shaked I, Shevach E, Schwartz M. Neuroprotective autoimmunity: naturally occurring CD4+CD25+ regulatory $\mathrm{T}$ cells suppress the ability to withstand injury to the central nervous system. Proc Natl Acad Sci USA. (2002) 99:15620-5. doi: 10.1073/pnas.232565399

141. Kil K, Zang YC, Yang D, Markowski J, Fuoco GS, Vendetti GC, et al. $\mathrm{T}$ cell responses to myelin basic protein in patients with spinal cord injury and multiple sclerosis. J Neuroimmunol. (1999) 98:201-7. doi: 10.1016/S0165-5728(99)00057-0

142. Jones TB, Hart RP, Popovich PG. Molecular control of physiological and pathological T-cell recruitment after mouse spinal cord injury. J Neurosci. (2005) 25:6576-83. doi: 10.1523/JNEUROSCI.0305-05.2005

143. Ibarra A, Jiménez A, Cortes C, Correa D. Influence of the intensity, level and phase of spinal cord injury on the proliferation of $\mathrm{T}$ cells and T-cell-dependent antibody reactions in rats. Spinal Cord. (2006) 45:380. doi: 10.1038/sj.sc.3101972

144. Zajarías-Fainsod D, Carrillo-Ruiz J, Mestre H, Grijalva I, Madrazo I, Ibarra A. Autoreactivity against myelin basic protein in patients with chronic paraplegia. Eur Spine J. (2012) 21:964-70. doi: 10.1007/s00586-0112060-7

145. Davies AL, Hayes KC, Dekaban GA. Clinical correlates of elevated serum concentrations of cytokines and autoantibodies in patients with spinal cord injury. Arch Phys Med Rehabil. (2007) 88:1384-93. doi: 10.1016/j.apmr.2007.08.004

146. Olsson T, Diener P, Ljungdahl A, Hojeberg B, van der Meide PH, Kristensson K. Facial nerve transection causes expansion of myelin autoreactive $\mathrm{T}$ cells in regional lymph nodes and $\mathrm{T}$ cell homing to the facial nucleus. Autoimmunity. (1992) 13:117-26. doi: 10.3109/08916939209001912

147. Hauben E, Butovsky O, Nevo U, Yoles E, Moalem G, Agranov E, et al. Passive or active immunization with myelin basic protein promotes recovery from spinal cord contusion. J Neurosci. (2000) 20:6421. doi: 10.1523/JNEUROSCI.20-17-06421.2000

148. Jones TB, Basso DM, Sodhi A, Pan JZ, Hart RP, MacCallum RC, et al. Pathological CNS autoimmune disease triggered by traumatic spinal cord injury: implications for autoimmune vaccine therapy. J Neurosci. (2002) 22:2690-700. doi: 10.1523/JNEUROSCI.22-07-02690.2002

149. Muhallab S, Lundberg C, Gielen AW, Lidman O, Svenningsson A, Piehl F, et al. Differential expression of neurotrophic factors and inflammatory cytokines by myelin basic protein-specific and other recruited $\mathrm{T}$ cells infiltrating the central nervous system during experimental autoimmune encephalomyelitis. Scand J Immunol. (2002) 55:264-73. doi: $10.1046 / j .0300-9475.2002 .01038 . x$

150. Olsson T, Lidman O, Piehl F. Harm or heal-divergent effects of autoimmune neuroinflammation? Trends Immunol. (2003) 24:5-6; author reply 7-8. doi: 10.1016/S1471-4906(02)00003-0

151. Walsh JT, Hendrix S, Boato F, Smirnov I, Zheng J, Lukens JR, et al. MHCIIindependent $\mathrm{CD} 4+\mathrm{T}$ cells protect injured CNS neurons via IL-4. J Clin Invest. (2015) 125:699-714. doi: 10.1172/JCI76210

152. Arevalo-Martin A, Grassner L, Garcia-Ovejero D, Paniagua-Torija B, Barroso-Garcia G, Arandilla AG, et al. Elevated autoantibodies in subacute human spinal cord injury are naturally occurring antibodies. Front Immunol. (2018) 9:2365. doi: 10.3389/fimmu.2018.02365

153. Saltzman JW, Battaglino RA, Salles L, Jha P, Sudhakar S, Garshick E, et al. Bcell maturation antigen, a proliferation-inducing ligand, and B-cell activating factor are candidate mediators of spinal cord injury-induced autoimmunity. J Neurotrauma. (2013) 30:434-40. doi: 10.1089/neu.2012.2501

Conflict of Interest Statement: The authors declare that the research was conducted in the absence of any commercial or financial relationships that could be construed as a potential conflict of interest.

Copyright $\odot 2019$ Javidi and Magnus. This is an open-access article distributed under the terms of the Creative Commons Attribution License (CC BY). The use, distribution or reproduction in other forums is permitted, provided the original author(s) and the copyright owner(s) are credited and that the original publication in this journal is cited, in accordance with accepted academic practice. No use, distribution or reproduction is permitted which does not comply with these terms. 